\title{
$\alpha^{\prime \prime}-\mathrm{Fe}_{16} \mathrm{~N}_{2}$ の結晶構造と磁性
}

早大・院 (現阪大・院) ${ }^{1} 、$ 阪大産研 ${ }^{2} 、$ 東工大工 ${ }^{3} 、$ 早大理工 ${ }^{4}$ 田中啓文 ${ }^{1} 、$ 中田芳幸 2 、弘津禎彦 2 、中村吉男 3 、長倉繁黁4

[はじめに] 1971 年 $\mathrm{Kim}$ と高橋は $\alpha^{\prime \prime}-\mathrm{Fe}_{16} \mathrm{~N}_{2}$ （以下 $\alpha^{\prime \prime}$ ）が室温において既存の磁性材料では 最高の 2250G という飽和磁化を有することを発見した。さらに、1989 年杉田らは MBE 法で $\alpha "$ 単絬昆薄膜を作製し、その下大飽和磁化を実証した。このため、近尔 $\alpha^{\prime \prime}$ は磁性材料として脚光 を浴びており、数多くの砛究者がその砄究を行っている。しかしその重要性にもかかわらず、 1951 年の Jack による $\alpha$ " の発見以来、その構造解析などの基礎研究は行われていない。そこで本 研究ではイメージングプレート (IP) を利用した $\alpha$ "の電子線構造解析を行うとともに、得られた 構造を基にバンド計算を行い $\alpha$ " の磁性を評価することを目的とする。

[実験方法] 本研究では、窒素鎆マルテンサイトを焼き戻すことにより $\alpha$ "を析出させた試料を 用いた。使用した電子顕微鏡は加速電圧 $300 \mathrm{kV}$ のJEM-3010である。IP により得られた電子回折 強度を解析し観測強度とした。理論強度には温度因子を考虑したマルチスライス法による計算値 を用いた。観測強度と計算強度の比較を行い、R 因子が最小になるものを $\alpha^{\prime \prime}$ の正しい構造とし た。バンド計算には東大の浅野による linear augmented plane wave ( LAPW ) 法のプログラムを用 いた。計算条件は、球面波展開における角運動量のカットオフ值は 8、展開平面波数は約 1500 、 既約なブリルアンゾーン内で設定した $k$ 空間のサンプル点は 14 点である。計算は我々の結晶構 造データについて行ったほか、Jack のモテルなどについても行い、各々の結果を比較した。

[結果] 電子回折写真を解析した結果 $\alpha$ " の格子定数は $a "=b "=5.72 \AA 、 c "=6.31 \AA$ で軸比は $\mathrm{c} / \mathrm{a}$ $=1.103$ であった。電子回折強度測定から $4 \mathrm{e}$ 位置の鉄原子位置パラメータは $\mathrm{z}=1 / 4+\Delta z, \Delta z=0.053$ であることが分かった。また、8h 位置の鉄原子位置パラメータは $\mathrm{x}=1 / 4-\Delta \mathrm{x}, \Delta \mathrm{x}=0.030$ であるこ とが分かった。図 1 に構造解析で分かった $\alpha^{\prime \prime}$ の (110)断面を示す。Fe8h が Jack のモデルよりも 窒素原子の方へ変位していることが分かる。またバンド計算から、 $\alpha$ ににおけるマフィンティン 球内の鉄原子の局所磁気モ一メントの大きさは、我々の構造テータによると Fe8h , Fe 4e , Fe 4d の 順に大きく、Jack の構造モテルによるとFe4e , Fe8h , Fe4dの順に大きい結果を得た。図 2 に Fe8h の変位 $\Delta \mathrm{x}$ と各サイトの鉄原子の局所磁気モーメントの関係を示す。両者で Fe4e と Fe8h の磁気 モーメントの大きさが逆転したのは、空素原子に対する第一近接と第二近接の Fe 原子位置が、 我々の構造データとJackのモデルで入れ替わったためと考えられる。

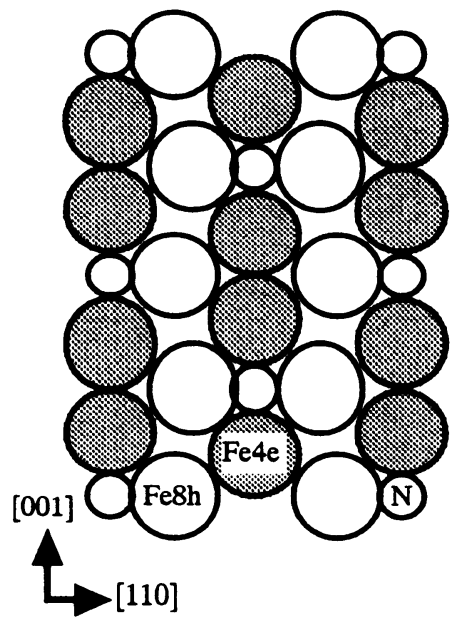

図1; $\alpha$ "- $\mathrm{Fe}_{16} \mathrm{~N}_{2}$ の (110) 面

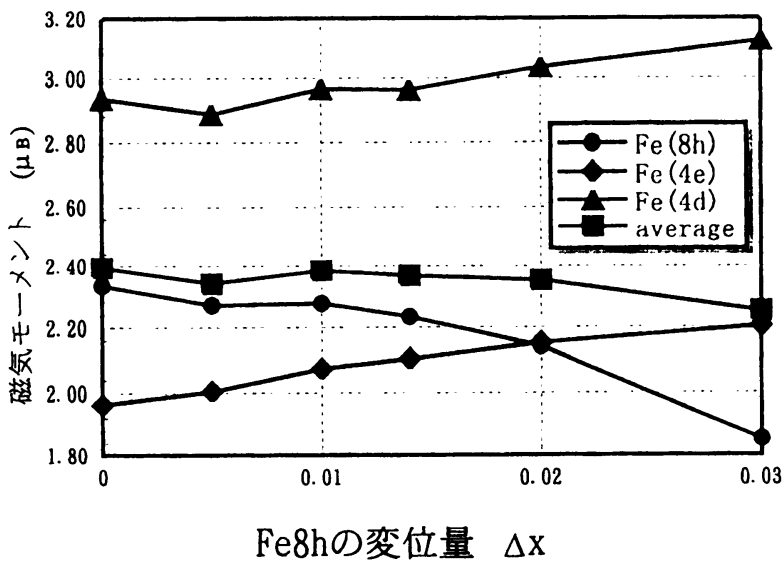

因2; $\mathrm{Fe}(8 \mathrm{~h})$ 0)変位 $\Delta \mathrm{x}$ と各サイトの 鉄原子の局所磁気モーメントの関係 